\title{
Oversettelse og psykometrisk testing av The Family Collaboration Scale
}

\section{Instrumentet måler samarbeid mellom pleiepersonale og pårørende til svekkete, akuttinnlagte eldre. En norsk versjon skal gjøre det tilgjengelig i vår kliniske praksis og forskning.}

\section{FORFATTERE}

\section{Jill-Marit Moholt}

Intensivsykepleier og stipendiat

Senter for omsorgsforskning, nord, Institutt for helse og omsorgsfag, UiT Norges arktiske universitet

Tove Aminda Hanssen

Fag- og forskningssykepleier og postdoktorstipendiat

Hjerte- og lungeklinikken, Universitetssykehuset Nord-Norge og Kardiovaskulær forskningsgruppe IKM, UiT, Norges arktiske universitet

\section{NøKKELORD}

Eldre, Pårørende, Samarbeid, Spørreskjema, Sykepleie

\section{SAMMENDRAG}

Bakgrunn: Instrumentet The Family Collaboration Scale (FCS) er utviklet for å undersøke pårørendes opplevelser rundt samarbeid med pleiepersonalet når svekkete eldre er akutt innlagt i sykehus.

Hensikt: Studiens hensikt var å oversette FCS fra dansk til norsk. Vi ønsket også å teste de måletekniske egenskapene til den oversatte versjonen på et utvalg pårørende til svekkete eldre pasienter etter akutt innleggelse for medisinsk behandling i sykehus.

Metode: Instrumentet ble oversatt etter internasjonale kriterier. Den norske versjonen er testet i en tverrsnittsstudie med 147 pårørende til pasienter over 65 år. Reliabilitet er testet gjennom analyser av intern konsistens og test-retest. Validitet er vurdert gjennom bedømming av innholds- og begrepsvaliditet.

Resultat: Reliabilitet analysert med Cronbachs alfa og intraklassekorrelasjonskoeffisient (ICC) viste verdier over 0,7 for de fem opprinnelige dimensjonene. En ekspertgruppe og pårørende bedømte innholdsvaliditeten som tilfredsstillende. Begrepsvaliditet, vurdert gjennom eksplorerende faktoranalyse, viste at den opprinnelige dimensjonsstrukturen i noen grad ble gjenskapt, men det framkom tre nye faktorer.

Konklusjon: Den norske versjonen av FCS er i hovedsak et reliabelt og valid instrument for å måle pårørendes erfaringer relatert til samarbeid med pleiepersonalet når svekkete eldre pasienter er akutt innlagt i sykehus. Før instrumentet brukes i forskning og praksis, anbefaler vi videre testing på et større 
De fleste innleggelser av eldre pasienter på somatisk sykehus er akutt betinget (1). Helsepersonell er forpliktet til å involvere pasienten i behandling og pleie, og det er knyttet lovpålagte rettigheter til pasientrollen, slik som rett til informasjon og medvirkning (2). Brukermedvirkning fordrer aktive og delaktige pasienter (3), men mange eldre er lite forberedt på å delta i slike prosesser (4).

Forskning viser at noen ikke medvirker på grunn av manglende ressurser under sykehusinnleggelsen (5). Blant annet kan sykdom og svekkelse medføre at det er vanskelig å forstå og håndtere innholdet i informasjonen som gis (6). I en studie om eldre pasienters utskrivelsesprosesser viser resultatene at pasientene ønsker å medvirke, men dette $\emptyset$ nsket ble stort sett ikke møtt av helsepersonellet. Over halvparten av deltakerne fikk få anledninger eller ikke anledning til å fortelle hva som var viktig for at de skulle klare seg selv etter utskrivelsen $(5,7)$. Over en tredel $\emptyset$ nsket å få informasjon sammen med pårørende, og nesten halvparten oppga at de ikke hadde fått tilbud om slik informasjon (5).

\section{PÅRØRENDE SOM RESSURS ELLER UTFORDRER}

I meldingen til Stortinget «God kvalitet - trygge tjenester - Kvalitet og pasientsikkerhet i helse- og omsorgstjenesten» (3) blir pårørende karakterisert som en uvurderlig ressurs. De har ofte verdifull kunnskap om den sykes bakgrunn, sykehistorie, ressurser og erfaringer fra tidligere behandling. De kan innta rollen som pasientens talsperson, bidra til koordinering mellom de ulike helsetjenestene og hjelpe pasienten med å håndtere informasjon og opplysninger dersom pasienten samtykker til dette (3).

Pårørendes rolle under sykehusinnleggelse er også belyst innen forskning. Pårørende ser på seg selv som pasientens støttespillere som ønsker å påse at pasientens interesser og behov blir ivaretatt. Dersom de har vært involvert i hjelpe- og pleieoppgaver før innleggelse, kan de likevel føle ansvar selv om disse oppgavene blir ivaretatt av pleiepersonalet $(8,9)$.

\section{«Til tross for teoretiske og politiske idealer viser studier at samarbeid mellom sykepleiere og pårørende er preget av utfordringer.»}

Ivaretakelse og samarbeid med pårørende er ansett som god sykepleiepraksis (10-12), som kan sikre pasientens rett til brukermedvirkning (3). Til tross for teoretiske og politiske idealer viser studier at samarbeid mellom sykepleiere og pårørende er preget av utfordringer (12-14). I utgangspunktet er sykepleiere positive til å samarbeide, men det kan være både krevende og tidskonsumerende $(12,13)$. Samarbeid kan hindres av utilstrekkelig kommunikasjon (13) eller av konflikter dersom pårørende utfordrer sykepleierne ved å involvere seg i pleie av pasienten $(8,12)$.

\section{KARTLEGGER PÅRøRENDES PERSPEKTIV}


Forskning viser signifikante sammenhenger mellom pårørendes muligheter til å delta i samarbeidsprosesser og deres vurdering av kvaliteten på pleien i sykehjem (15). Det er også funnet sammenheng mellom pårørendes grad av tilfredshet med sykehusoppholdet og samarbeidet med sykepleiere (16). Det er derfor nærliggende å anta at pårørendes erfaringer med samarbeid kan knyttes til opplevelsen av tilfredshet og kvalitet (17).

Basert på gjennomgang av tidligere forskning og kontakt med internasjonale forskningsmiljøer fant Lindhardt og medarbeidere (17) at det ikke eksisterte tilgjengelige instrumenter som kartla pårørendes perspektiv på samarbeid med pleiepersonalet når svekkete eldre var innlagt i somatisk sykehus. De utviklet derfor instrumentet The Family Collaboration Scale (FCS) gjennom en prosess som besto av å velge ut relevante variabler, utvikle spørsmål og svaralternativer samt utforme logisk struktur. Dette arbeidet bygger til dels på to kvalitative studier der de intervjuet henholdsvis pårørende og sykepleiere $(11,12)$. FCS inneholder fem dimensjoner, som alle måler ulike egenskaper ved begrepet samarbeid:

- innflytelse på avgjørelser

- kvalitet på kontakt med pleiepersonalet

- tillit og forutsetninger for tillit

- informasjon

- innflytelse på utskrivelsesprosessen

Lindhardt og medarbeidere testet instrumentet på et dansk utvalg og vurderte de måletekniske egenskapene som tilfredsstillende (17).

Hensikten med en norsk versjon av FCS er å gjøre instrumentet tilgjengelig i klinisk praksis og forskning. Instrumentet identifiserer barrierer for samarbeid og resultat av samarbeid i form av pårørendes tilfredshet, informasjonsnivå og kvalitet på sykehusoppholdet. Det identifiserer dessuten hvorvidt det finner sted et samarbeid mellom pårørende og pleiepersonale $(16,17)$.

Bruk av instrumentet kan bidra til økt oppmerksomhet på samarbeid med og inkludering av pårørende når pasientene ønsker det, noe som igjen kan fremme brukermedvirkningsprosesser og forbedre kvaliteten på pleie og behandling av eldre pasienter innlagt i sykehus.

\section{HENSIKT MED STUDIEN}

Hensikten med denne studien var å oversette FCS fra dansk til norsk og teste de måletekniske egenskapene til den oversatte versjonen i et utvalg av pårørende til svekkete eldre pasienter etter akutt innleggelse for medisinsk behandling i sykehus.

\section{METODE}

\section{OVERSETTELSE OG PRETEST AV FCS}

Vi oversatte og tilpasset den norske versjonen av FCS i samsvar med en sekvensiell oversettelsesprosedyre (18-20) (figur 1). To separate translat $\varnothing$ rer oversatte instrumentet fra dansk til norsk. Første oversetter var tospråklig og godkjent translat $\varnothing r$, og andre oversetter var en sykepleier med lang erfaring fra klinisk praksis og med gode ferdigheter i dansk. Ulik bakgrunn var i samsvar med teoretiske anbefalinger, som sier at den ene translat $\varnothing$ ren bør være språklig ekspert, og den andre bør ha særskilt kompetanse om temaet som skal studeres (20-22). 
Figur 1: Flytskjema som framviser de ulike fasene i oversettelsesprosedyren av FCS fra dansk til norsk

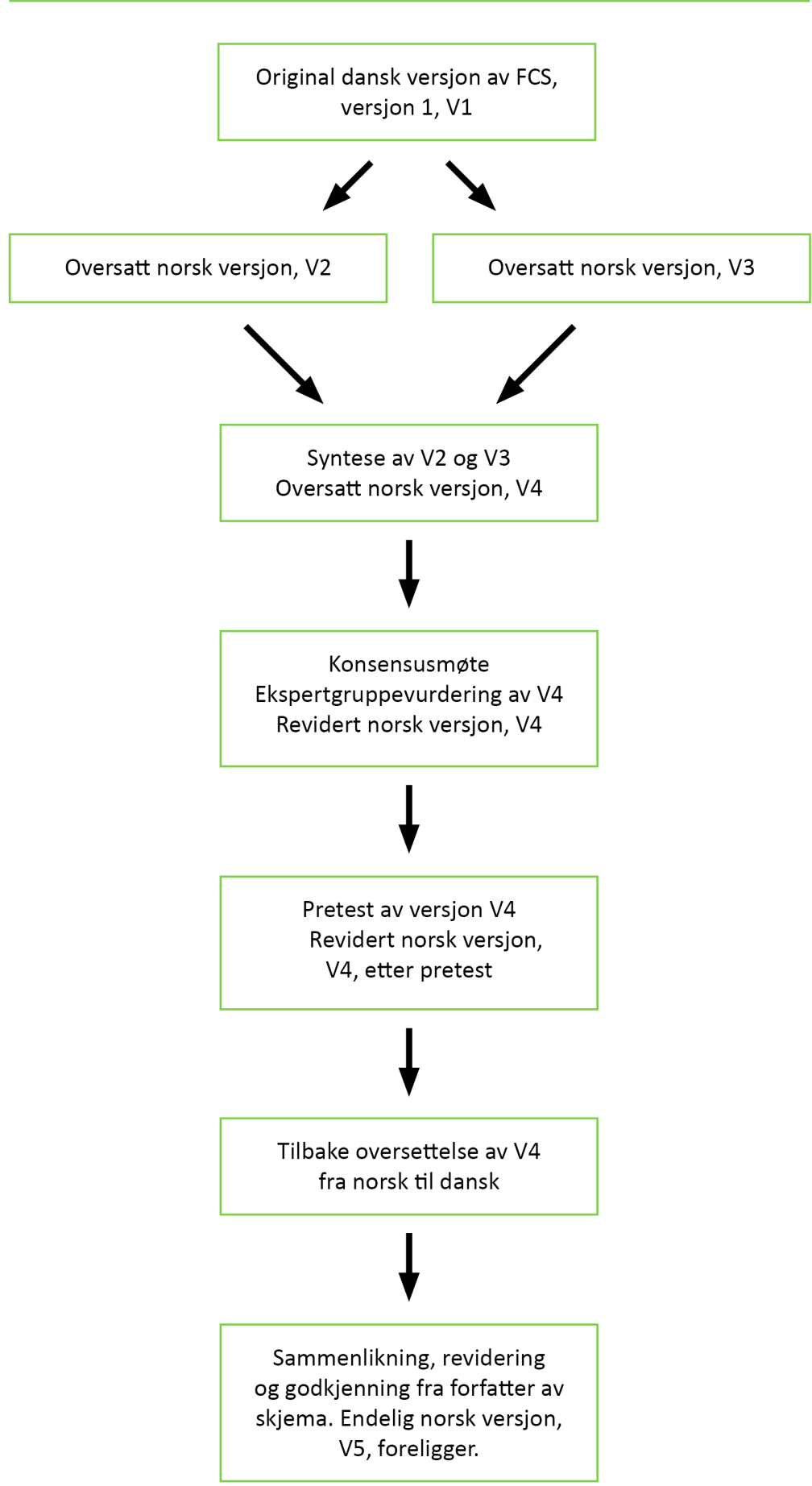

Vi utførte en syntese av de oversatte versjonene. Denne syntesen ble gjennomgått av en konsensusgruppe bestående av en dansk overlege og to sykepleiere med forskningskompetanse og klinisk kompetanse fra geriatrifeltet. Mandatet til gruppen var å drøfte likheter og ulikheter mellom den originale og den oversatte versjonen samt komme med forslag til tilpassinger.

Videre fremla vi den norske versjonen for en ekspertgruppe bestående av fire sykepleiere 
med lang klinisk erfaring fra eldreomsorg. De ble bedt om å vurdere ordlyd, spørsmålenes relevans og helheten i skjemaet. Deretter pretestet vi instrumentet blant fem pårørende til syke, eldre pasienter som nylig hadde vært innlagt på somatisk sykehus med akutt sykdom. Vi foretok et personlig intervju etter utfylling og ba pårørende om å fortelle hvorvidt spørsmålene opplevdes som forståelige og meningsfulle. Vi ba dem også om å komme med forslag til endringer.

I den opprinnelige danske versjonen ble begrepet «sykepleiepersonalet» brukt i flere av spørsmålene. Ifølge den danske forfatteren viste begrepet til alle yrkesgruppene som er involvert i pleie av pasientene under sykehusinnleggelsen. Vi diskuterte begrepet med både ekspertgruppen og pårørende, og de fleste relaterte det til sykepleieutdannet personale. Flere av de pårørende mente det var vanskelig å skille mellom sykepleiere og annet pleiepersonale når de skulle rapportere om sine opplevelser, og de foretrakk derfor ordlyden «pleiepersonalet» i den norske versjonen av instrumentet.

Underveis i oversettelsesprosessen utføre vi mindre endringer og tilpassinger av begreper slik at de bedre samsvarte med generell norsk språkbruk. En ny, uavhengig, profesjonell, tospråklig translatør oversatte redigert versjon tilbake fra norsk til dansk. Vi oversendte de ulike versjonene samt dokumentasjon fra oversettelsesprosedyren til forfatteren av spørreskjemaet. Den danske forfatteren har arbeidet flere år i Norge og har god kjennskap til norsk språk og begrepsbruk. Hun anbefalte kun mindre endringer av enkeltord for å sikre ekvivalens mellom den norske og den opprinnelige versjonen.

\section{TEST AV FCS}

Et instruments måletekniske egenskaper viser til testing utført i en spesifikk målgruppe under gitte omstendigheter. Det er derfor viktig å teste psykometriske egenskaper når instrumentet skal brukes i en annen kultur eller i en annen målgruppe (18, 20, 22). Vi prøvde ut den norske versjonen av FCS ved å bruke en tverrsnittsunders $\varnothing$ kelse.

\section{UTVALG OG DATAINNSAMLING}

Vi utførte studien på åtte medisinske sengeposter ved et universitetssykehus. Det var nødvendig med et nært samarbeid med pleiepersonalet for å rekruttere deltakere. På tre av sengepostene hadde godkjente studiemedhjelpere ansvaret for rekrutteringen.

Inklusjonskriterier for pasientene var at de skulle være over 65 år og innlagt med akutt sykdom eller forverring av kronisk sykdom. De måtte være hjemmeboende forut for sykehusinnleggelsen, ha svekket helse relatert til en eller flere sykdommer, og ha behov for hjelp og støtte i dagliglivet. De måtte være samtykkekompetente, det vil si beherske norsk i tilstrekkelig grad og ikke ha konjunktiv svekkelse. Pasientene mottok skriftlig og muntlig informasjon. De som ønsket å delta, ga skriftlig informert samtykke, slik at vi kunne kontakte den pårørende som ifølge pasienten var mest delaktig i hjelp og støtte, og som hadde vært til stede under sykehusoppholdet.

Fjorten dager etter at pasienten var utskrevet fra sykehuset, fikk de pårørende tilsendt informasjonsbrev med forespørsel om deltakelse, spørreskjema (vedlegg 1) og frankert svarkonvolutt til retur av spørreskjema. Vi utførte en selektiv påminnelsesprosedyre per telefon tre uker etter første utsendelse. Retur av spørreskjemaet ble regnet som samtykke til deltakelse.

\section{SP $\emptyset$ RRESKJEMAET FCS}

FCS er satt sammen av 27 spørsmål, som totalt inneholder 45 Likert-skalaer, og som utgjør de ulike dimensjonene i instrumentet. I tillegg medregnes ni kategoriske variabler i instrumentet (vedlegg 1, spørsmål 20-56). Responsalternativene på Likert-skalaene er 
rangert fra 1-4 eller fra 1-6, der lav skår indikerer høy grad av samarbeid.

Spørreskjemaet inneholdt også ni sosiodemografiske spørsmål om pårørende (spørsmål 1-9) og fem kategoriske variabler som kartla omfanget av hjelp som pårørende ga (spørsmål 10-14). Fem spørsmål om pårørendes opplevelser (spørsmål 15-19), og det åpne spørsmålet på slutten av skjemaet var ikke en del av instrumentet FCS, og ble derfor ikke analysert i denne studien.

Vi laget tre spørsmål for denne studien som finnes avslutningsvis i spørreskjemaet (vedlegg 1 ). Disse spørsmålene kartla hvilken avdeling den eldre var innlagt på, og hva som var årsaken til innleggelsen. I tillegg omhandlet ett spørsmål hvorvidt pårørende ønsket å fylle ut spørreskjemaet én gang til etter to til tre uker for å teste instrumentets stabilitet gjennom en repetert måling.

\section{ANALYSER}

Vi skannet inn data fra utfylte spørreskjemaer i en database. Deretter kodet, skåret og summerte vi dataene i dimensjoner med utgangspunkt i skåringsbeskrivelse utarbeidet av forfatteren av spørreskjemaet (17). Vi summerte og transformerte spørsmål i hver dimensjon til verdier mellom 0-100, der høyere skårer indikerte at pårørende var mindre tilfredse eller opplevde mindre samarbeid med pleiepersonalet. I spørsmål med flere svaralternativer ble antall svar summert.

Vi utførte analysene med statistikkprogrammet SPSS versjon 21.0. Deskriptiv statistikk ble brukt for å analysere sosiodemografiske variabler og typen hjelp som pårørende bidro med, og for å få overblikk over skjemaets dimensjoner. Vi bedømte reliabilitet gjennom analyser av intern konsistens (Cronbachs alfa og enkeltspørsmålenes korrelasjon med hver delskala) og stabilitet (test-retest-reliabilitet).

Stabilitet ble analysert med intraklassekorrelasjonskoeffisient (ICC agreement) gjennom variasjonsmåling av gjennomsnittsskår og repetert gjennomsnittsskår fra deltakerne som svarte på FCS to ganger. Ekspertgruppen og pretestdeltakerne bedømte instrumentets innholdsvaliditet i oversettelsesprosessen og vurderte skjemaet som helhet, enkeltspørsmålenes egnethet og hvorvidt de var dekkende for å måle samarbeid med pleiepersonalet. Vi analyserte begrepsvaliditet med eksplorerende faktoranalyse (EFA), med Principal Component Analyses (PCA) som ekstraksjonsmetode og Varimax-rotasjon.

Vi vektla å utføre analysene på samme måte som forfatteren av spørreskjemaet har beskrevet i test av den danske versjonen (17) for å kunne sammenlikne resultatene. Totalt 44 spørsmål inngikk i EFA. Kaiser-Meyer-Olkin-test (KMO-test) på 0,81 indikerte at utvalgsstørrelsen var tilstrekkelig (23). Bartletts test for alle korrelasjoner var signifikant ( $p$ $<0,001)$, og analysen var dermed berettiget (23).

Spearman's rank order-korrelasjon (Spearman's rho) ble brukt for å analysere korrelasjon mellom spørsmålene i hver enkelt dimensjon og mellom de ulike dimensjonene.

Signifikansnivå ble satt til $p<=0,05$.

\section{ETISKE ASPEKTER}

Studien var godkjent av klinikksjefer, og i tillegg informerte vi avdelingsledere, avdelingssykepleiere og pleiepersonalet skriftlig og muntlig før rekrutteringen startet. Studien var ifølge Regionale komiteer for medisinsk og helsefaglig forskningsetikk (REK) ikke framleggingspliktig. Universitetssykehusets eget personvernombud (PVO) godkjente studien og ga direktiver for anonymisering og oppbevaring av data. Vi holdt en liste med navn og korresponderende ID-nummer innelåst og utilgjengelig for uvedkommende i 
rekrutteringsperioden, og slettet listen ved studiens slutt.

\section{RESULTATER}

Vi forespurte i alt 243 pasienter, og av disse samtykket 230 til at vi kunne kontakte deres pårørende. Totalt sju deltakere ble ekskludert på grunn av dødsfall etter samtykke $(n=3)$, mangelfulle pårørendeopplysninger $(n=2)$, alder $(n=1)$ eller benyttelse av pasientens rett til å trekke samtykket $(n=1)$. Vi sendte ut 223 spørreskjemaer, og totalt 147 pårørende returnerte ferdig utfylt skjema (66 prosent). Alle pårørende fikk spørsmål om de var villige til å fylle ut spørreskjemaet én gang til etter tre uker for å kunne utføre en stabilitetsanalyse, og 22 pårørende gjorde dette.

Vi presenterer en oversikt over sosiodemografiske variabler i tabell 1. Den typiske deltakeren var en gift eller samboende kvinne på 58,5 år med høyere utdanning, og som var yrkesaktiv. Hun var datter av den eldre pasienten, og de bodde ikke sammen.

Tabell 1: Sosiodemografiske karakteristika $(n=147)$

\begin{tabular}{|c|c|}
\hline \multicolumn{2}{|l|}{ Alder $(n=146)$} \\
\hline Gjennomsnittsalder (SD) i år & $58,5(12,2)$ \\
\hline Variasjonsbredde i år & $21-85$ \\
\hline \multicolumn{2}{|l|}{ Kjønn, n (\%) } \\
\hline Menn & $33(22,4)$ \\
\hline Kvinner & $114(77,6)$ \\
\hline \multicolumn{2}{|l|}{ Sivilstand ( $n=142), n(\%)$} \\
\hline Gift/samboer & $119(81,5)$ \\
\hline Ugift/fraskilt & $23(15,8)$ \\
\hline Enke/enkemann & $4(2,7)$ \\
\hline \multicolumn{2}{|c|}{ Relasjon til den eldre $(n=144), n(\%)$} \\
\hline Ektefelle & $46(31,9)$ \\
\hline Datter/sønn & $83(57,6)$ \\
\hline Andre & $15(10,5)$ \\
\hline \multicolumn{2}{|l|}{ Bor sammen med den eldre, $n(\%)$} \\
\hline $\mathrm{Ja}$ & $55(37,4)$ \\
\hline $\mathrm{Nei}$ & $92(62,6)$ \\
\hline \multicolumn{2}{|c|}{ Om nei, avstand fra den eldres bopel $(n=91), n(\%)$} \\
\hline Mindre enn $20 \mathrm{~km}$ & $40(44 \%)$ \\
\hline Mer enn 20 km & $51(56 \%)$ \\
\hline \multicolumn{2}{|c|}{ Høyeste fullførte utdanning ( $n=146), n(\%)$} \\
\hline Grunnskole & $36(24,7)$ \\
\hline Videregående skole & $44(30,1)$ \\
\hline Universitet eller høyskole & $66(45,2)$ \\
\hline \multicolumn{2}{|c|}{ Utdannet helsepersonell $(n=146), n(\%)$} \\
\hline $\mathrm{Ja}$ & $36(24,7)$ \\
\hline $\mathrm{Nei}$ & $110(75,3)$ \\
\hline \multicolumn{2}{|l|}{ Yrkesaktiv ( $n=146), n$ (\%) } \\
\hline $\mathrm{Ja}$ & $90(61,6)$ \\
\hline $\mathrm{Nei}$ & $56(38,4)$ \\
\hline
\end{tabular}

SD: Standardavvik 
som pårørende ga til de eldre. I tillegg viste analyser at pårørende i hovedsak var involvert i hjelpeoppgaver som psykisk støtte og oppmuntring ( 58 prosent), praktisk hjelp i hjemmet (57 prosent), ledsagerhjelp (57 prosent) og innkjøp (57 prosent). Færre utførte personlig hjelp som kroppsvask, toalettbes $\varnothing \mathrm{k}$, hårvask og hjelp til spising (22 prosent) eller trening (3 prosent).

Tabell 2: Hjelpeinnsats før sykehusinnleggelse $(n=147)$

\begin{tabular}{|c|c|}
\hline \multicolumn{2}{|c|}{ Hvor ofte pårørende yter hjelp $(n=146), n(\%)$} \\
\hline Aldri & $12(8,2)$ \\
\hline Mindre enn 1 gang i uken & $27(18,5)$ \\
\hline $2-3$ ganger per uke & $34(23,3)$ \\
\hline 4-6 ganger per uke & $17(11,6)$ \\
\hline Hver dag & $56(38,4)$ \\
\hline \multicolumn{2}{|c|}{ Resterende spørsmål ble besvart av dem som oppga at de ytet hjelp } \\
\hline \multicolumn{2}{|c|}{ Varighet av hjelperelasjon $(n=130), n(\%)$} \\
\hline Mindre enn 12 måneder & $35(26,1)$ \\
\hline $1-2$ år & $11(8,5)$ \\
\hline $3-5$ àr & $25(19,2)$ \\
\hline Mer enn 5 år & $59(45,4)$ \\
\hline \multicolumn{2}{|c|}{ Tid den eldre kan være alene $(n=131), n(\%)$} \\
\hline Mindre enn 2 timer & $14(10,7)$ \\
\hline 2-12 timer & $50(38,2)$ \\
\hline Mer enn 12 timer & $30(22,9)$ \\
\hline Ubegrenset & $37(28,2)$ \\
\hline
\end{tabular}

I tabell 3 presenterer vi resultatene for summariske mål for de fem opprinnelige dimensjonene i FCS. Dimensjonen «innflytelse på avgjørelser» hadde høyest gjennomsnittskår på 62,6. Dimensjonen «tillit og forutsetninger for tillit» hadde lavest gjennomsnittsskår. En markant venstrevridning av resultatet, det vil si mot laveste skår, indikerer at pårørende opplevde stor grad av tillit. «Innflytelse på utskrivelsen» hadde flest manglende svar. Dette kan ha sammenheng med at et spørsmål skulle besvares av respondenter som svarte «nei» på et innledende spørsmål, noe som førte til 29 prosent frafall på oppfølgingsspørsmålet.

\begin{tabular}{|c|c|c|c|c|c|c|c|}
\hline FCS & $\mathrm{n}$ & $\begin{array}{l}\text { Spørsmål } \\
\text { per skala }\end{array}$ & $\begin{array}{r}\text { Cronbachs } \\
\text { alfa }\end{array}$ & $\begin{array}{r}\text { Gj.snitt } \\
\text { (SD) }\end{array}$ & $\begin{array}{l}\text { Min.- } \\
\text { maks. }\end{array}$ & $\begin{array}{r}\text { Manglende } \\
\text { data* }^{*}\end{array}$ & $\begin{array}{r}\text { Item total } \\
\text { korrelasjon** }\end{array}$ \\
\hline Innflytelse på avgjørelser & 130 & 10 & 0,83 & $62,6(21,7)$ & $4,95-95,7$ & 2-15 & $0,35-0,76$ \\
\hline Kvalitet på kontakt med pleiepersonalet & 131 & 9 & 0,81 & $27,7(17,6)$ & $0-85,7$ & $1-8$ & $0,34-0,73$ \\
\hline Tillit og forutsetninger for tillit & 141 & 11 & 0,79 & $16,9(11,5)$ & $0-65,9$ & $0-3$ & $0,35-0,60$ \\
\hline Oppnådd informasjonsnivå & 138 & 5 & 0,73 & $45,7(19,1)$ & $10,0-100$ & $0-5$ & $0,27-0,67$ \\
\hline Innflytelse på utskrivelsen & 95 & 7 & 0,78 & $51,5(25,96)$ & $0-91,2$ & $0-42 x$ & $0,06-0,72$ \\
\hline $\begin{array}{l}\text { SD: Standardavvik } \\
\text { * Rangering av manglende data i spørsmål. } \\
\text { ** Minimum- og maksimumskår for spørsmå } \\
\text { ¿ Skalaen inneholder et sporsmål som skat b }\end{array}$ & $=$ inner & ikalaen. & (2. & 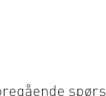 & & & \\
\hline
\end{tabular}

\section{RELIABILITETSANALYSER}

Intern konsistens, analysert med Cronbachs alfa, viste skår over 0,7 for alle de fem 
opprinnelige dimensjonene. Korrelasjonene mellom enkeltspørsmål og hver skala viste varierende korrelasjoner som et uttrykk for varierende overlapping mellom enkeltspørsmål og tilhørende skala (tabell 3). Test-retest-reliabilitet ble analysert med intraklassekorrelasjonskoeffisient (ICC agreement), og alle fem dimensjonene inntok verdier over 0,7 .

\section{VALIDITET}

Eksperter og pårørende bedømte innholdsvaliditet i pretest av spørreskjemaet. Begge gruppene vurderte at skjemaet hadde god umiddelbar validitet, og førsteinntrykket var at innholdet refererte til ulike sider av samarbeid mellom pårørende og helsepersonell. Alle pårørende påpekte at innholdet var lettfattelig, relevant og gjenkjennelig. Flere pårørende syntes spørreskjemaet var nyttig, da de hadde ulike erfaringer med å samarbeide med pleiepersonalet.

Spørsmål 32 (vedlegg 1) omhandlet hvorvidt problemet som førte til innleggelsen, ble løst. Dette spørsmålet var det eneste som ble fjernet fra faktoranalysen grunnet lav korrelasjon med de andre spørsmålene.

Totalt 44 spørsmål inngikk i faktoranalysen. I henhold til Kaisers kriterium (egenverdi > 1) og fortolkning av skreddiagram kunne åtte faktorer medregnes, og disse forklarte 61,5 prosent av total varians. To av de fem originale dimensjonene ble splittet, og det framkom tre nye faktorer. Tabell 4 presenterer en oversikt over faktorer og inkluderte spørsmålenes faktorladning $(>=0,3)$.

\begin{tabular}{|c|c|c|c|c|c|c|c|c|}
\hline Dimensjon med spørsmål & Faktor 1 & Faktor 2 & Faktor 3 & Faktor 4 & Faktor 5 & Faktor * $^{*}$ & Faktor $7^{*}$ & Faktor $8^{*}$ \\
\hline 1) Innflytelse på avgjørelser & $\begin{array}{l}\text { Innflytelse } \\
\text { py av- } \\
\text { gjorelser }\end{array}$ & $\begin{array}{l}\text { Innflytelse } \\
\text { pa ut- } \\
\text { skrivning }\end{array}$ & $\begin{array}{l}\text { Tillit og } \\
\text { forutsetning } \\
\text { for tillit }\end{array}$ & $\begin{array}{l}\text { Oppnádd } \\
\text { informasjon }\end{array}$ & $\begin{array}{l}\text { Kvalitet på } \\
\text { kontakt med } \\
\text { pleiere }\end{array}$ & $\begin{array}{c}\text { Fysiske } \\
\text { omgivelser }\end{array}$ & $\begin{array}{l}\text { Aksept for } \\
\text { parrorendes } \\
\text { situasjon }\end{array}$ & $\begin{array}{c}\text { Hypoighet } \\
\text { pa kontakt, } \\
\text { tilgjengelighet }\end{array}$ \\
\hline $\begin{array}{l}\text { Jeg hadde innflytelse på beslutninger } \\
\text { om pleie (spm. } 38 \text { b) }\end{array}$ & 0,878 & & & & & & & \\
\hline $\begin{array}{l}\text { Jeg hadde innflytelse på beslutninger } \\
\text { om behandling (spm. } 38 \text { a) }\end{array}$ & $\underline{0,873}$ & & & & & & & \\
\hline $\begin{array}{l}\text { Pleiepersonalet spurte meg om mine } \\
\text { synspunkter pă beslutninger (spm. 36) }\end{array}$ & 0,840 & & & & & & & \\
\hline $\begin{array}{l}\text { Min kunnskap om min pårdrende ble } \\
\text { brukt av pleiepersonalet (spm. 35) }\end{array}$ & $\underline{0,735}$ & & & & & & & \\
\hline $\begin{array}{l}\text { Jeg ble informert om beslutningene } \\
\text { tatt om pleie (spm. } 37 \mathrm{~b} \text { ) }\end{array}$ & $\underline{0,670}$ & & & & & & & 0,303 \\
\hline $\begin{array}{l}\text { Jeg ble informert om beslutningene } \\
\text { tatt om behandling (spm. } 37 \text { a) }\end{array}$ & $\underline{0.584}$ & 0,309 & & & & & & 0,416 \\
\hline $\begin{array}{l}\text { Jeg var tilfreds med den innflytelsen } \\
\text { jeg fikk (spm. 41) }\end{array}$ & 0,487 & 0,325 & & 0,403 & & & & \\
\hline $\begin{array}{l}\text { Pleiepersonalet ba meg fortelle hva jeg visste } \\
\text { om min părorendes situasjon (spm. 34) }\end{array}$ & $\underline{-0,486}$ & & & & & & & \\
\hline \multicolumn{9}{|l|}{ 2) Innflytelse på utskrivelse } \\
\hline $\begin{array}{l}\text { Jeg hadde innflytelse på beslutninger om } \\
\text { opplegget etter utskrivelse (spm. } 38 \mathrm{~d} \text { ) }\end{array}$ & & $\underline{0,806}$ & & & & & & \\
\hline $\begin{array}{l}\text { Jeg ble informert om beslutninger om } \\
\text { opplegget etter utskrivelse (spm. } 37 \mathrm{~d} \text { ) }\end{array}$ & & 0,788 & & & & & & \\
\hline $\begin{array}{l}\text { Jeg hadde innflytelse på beslutninger } \\
\text { tatt om utskrivelse (spm. } 38 \mathrm{c} \text { ) }\end{array}$ & & 0,774 & & & & & & \\
\hline $\begin{array}{l}\text { Jeg ble informert om beslutninger } \\
\text { tatt om utskrivelse (spm. } 37 \mathrm{c} \text { ) }\end{array}$ & & $\underline{0,740}$ & & & & & & \\
\hline $\begin{array}{l}\text { Grad av behov for informasjon om hvordan } \\
\text { jeg best kan hjelpe min părørende }\end{array}$ & - & & & 0,344 & & & & \\
\hline $\begin{array}{l}\text { Jeg var enig i planene for tiden etter } \\
\text { utskrivelsen (spm. 51) }\end{array}$ & & $\underline{0,319}$ & & 0,305 & & & & \\
\hline $\begin{array}{l}\text { Pleiepersonalet og jeg var enige om hva som } \\
\text { skulle skje med min părorende (spm. } 40 \text { ) }\end{array}$ & - & 0,416 & & & & & & \\
\hline 3) Tillit og forutsetninger for tillit & Faktor 1 & Faktor 2 & Faktor 3 & Faktor 4 & Faktor 5 & Faktor $6^{*}$ & Faktor 7* & Faktor $8^{*}$ \\
\hline $\begin{array}{l}\text { Jeg hadde tillit til at min pårorende fikk } \\
\text { nødvendig pleie under oppholdet (spm. 24) }\end{array}$ & & & 0,745 & & & & & \\
\hline $\begin{array}{l}\text { Jeg fikk inntrykk av at pleiepersonalet } \\
\text { var dyktig (spm. 29) }\end{array}$ & & & $\underline{0,717}$ & & & & & \\
\hline $\begin{array}{l}\text { Opplevelser av feil og utilistrekkelig pleie } \\
\text { under denne innleggelsen (spm. 22) }\end{array}$ & & & $\underline{0,696}$ & & & & & \\
\hline $\begin{array}{l}\text { Pleiepersonalet behandlet pasientene } \\
\text { med respekt (spm. 27) }\end{array}$ & & & $\underline{0,689}$ & & & & & \\
\hline $\begin{array}{l}\text { Jeg måtte passe på at min pårorende } \\
\text { fikk hjelpen han/hun trengte (spm. 25) }\end{array}$ & & & $\underline{0.681}$ & & & & & \\
\hline $\begin{array}{l}\text { Opplevelser av feil og utilistrekkelig pleie } \\
\text { under tidligere innleggelser (spm. 23) }\end{array}$ & & & $\underline{0.536}$ & & & & & \\
\hline $\begin{array}{l}\text { Jeg opplevde at pleiepersonalet hadde } \\
\text { det travelt (spm. 28) }\end{array}$ & & & - & & 0,307 & & & \\
\hline
\end{tabular}




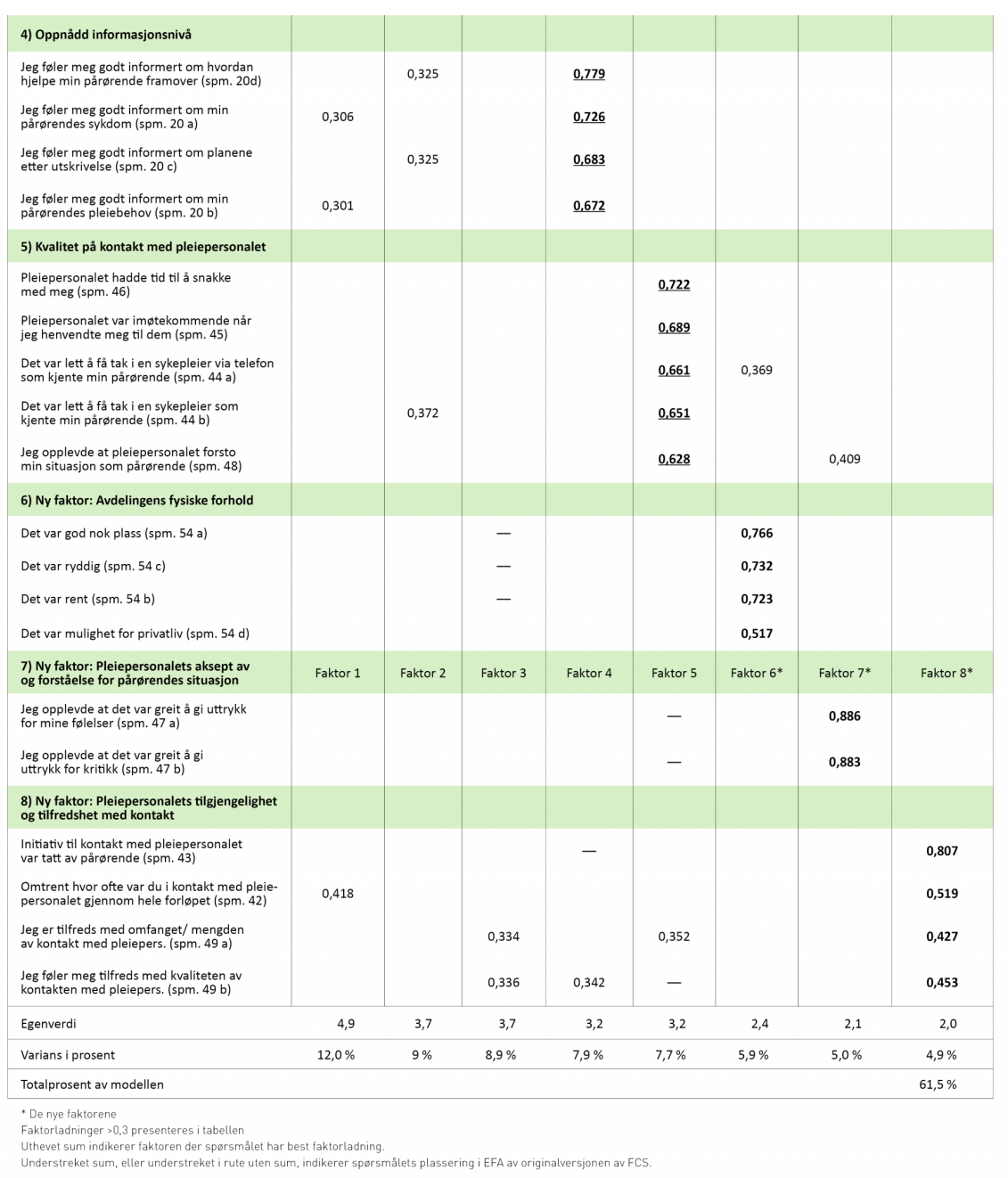

Første faktor gjenspeilet dimensjonen «innflytelse på avgjørelser», og totalt åtte av ti spørsmål ladet sterkest i denne. Analysens andre faktor var i overensstemmelse med dimensjonen «innflytelse på utskrivelse». Faktoren inneholdt fem av opprinnelig sju spørsmål, men ett spørsmål (spørsmål 51) ladet lavt. Faktor tre utgjorde delvis dimensjonen «tillit og forutsetninger for tillit», men fire av de opprinnelige spørsmålene dannet en ny faktor (faktor seks). Faktor fire er forenelig med dimensjonen «oppnådd informasjonsnivå», men spørsmål 43 falt inn under faktor åtte. Faktor fem er i noen grad samsvarende med dimensjonen «kvalitet på kontakt med pleiepersonalet» og inneholder fem av opprinnelig ni spørsmål. To av spørsmålene falt inn under faktor sju (spørsmål 47 a og b), og to ladet høyest i faktor åtte (spørsmål 49 a og b).

Verdiene for korrelasjon mellom de fem originale dimensjonene i FCS varierte fra 0,18 til 0,61 . Korrelasjon mellom spørsmålene i hver dimensjon bekreftet at spørsmålene som $\mathrm{i}$ faktoranalysen ladet lavt eller falt utenfor de originale dimensjonene, korrelerte lavt med de andre spørsmålene i de respektive dimensjonene.

\section{DISKUSJON}

Svarprosenten etter påminnelsesprosedyre (66 prosent) ansees som akseptabel for en spørreskjemaunders $\varnothing$ kelse (18). Vi utførte ikke frafallsanalyse, men frekvensanalyser indikerte at enkelte grupper var underrepresenterte. Bare 17 prosent av deltakerne var over 70 år, og i underkant av 25 prosent oppga grunnskole som høyeste utdanningsnivå. Dette er grupper som erfaringsmessig har høy frafallsprosent i spørreskjemaundersøkelser $(24,25)$. 
mellom teori og empiri, og instrumentet ble vurdert til å være reliabelt og valid innenfor testpopulasjonen (17). Den norske versjonen av FCS har tilfredsstillende intern konsistens $(18,21)$ for de fem originale dimensjonene. Høye skårer for ICC indikerer at den norske versjonen av FCS har stabile egenskaper, noe som er viktig for den totale reliabiliteten (26).

\section{ULIKE KULTURER KAN SPILLE INN}

Et begreps hypotetiske sammenhenger bør testes med konfirmerende faktoranalyse (CFA) (18). I denne studien var ikke dette en berettiget metode da utvalgsst $\varnothing$ rrelsen ikke oppfylte kriteriene for analysen (27). Vi vurderte derfor instrumentets begrepsvaliditet ved å analysere instrumentets struktur ved å bruke eksplorerende faktoranalyse (EFA), som er velegnet for å vurdere forskjeller mellom originalt og oversatt instrument (21).

\section{"Selv om det antas at der er få kulturelle forskjeller mellom Danmark og Norge, kan ulikheter tilskrives organisering av pleie og omsorg.»}

Spørsmål som ikke lader i sine opprinnelige faktorer etter oversettelse, kan indikere at de ikke oppfattes likt i de ulike kulturene (21). Selv om det antas at der er få kulturelle forskjeller mellom Danmark og Norge, kan ulikheter tilskrives organisering av pleie og omsorg. Det kan også være at pårørende har ulike forventninger til samarbeid og brukermedvirkning, uten at dette vites med sikkerhet.

Sp $\varnothing r s m a ̊ l ~ b \varnothing r$ ha faktorladning $>=0,4$ innenfor tilh $\varnothing$ rende dimensjon $(23,25)$. Totalt 13 av spørsmålene ladet lavt, slik at de ikke kan relateres til de originale dimensjonene (tabell 4). I denne studien betyr dette at de ikke kan knyttes til egenskapene de opprinnelig var satt til å måle. I tillegg viser analysen at fire enkeltspørsmål har $h \varnothing y$ faktorladning $>0,4$ i flere dimensjoner, noe som vanskeliggjør fortolkningen av deres faktortilhørighet (21).

\section{ANNET RESULTAT VED BRUK PÅ ANDRE POPULASJONER}

Den første av de nye faktorene (faktor seks) består av fire spørsmål som omhandler avdelingens fysiske forhold (tabell 4, spørsmål 54 a-d), og som opprinnelig tilhørte dimensjonen «tillit og forutsetninger for tillit». Teoretisk settes spørsmålene i sammenheng med at kontekstuelle forhold $i$ et sykehusmiljø kan være barrierer for samarbeid, og som igjen kan ha betydning for pårørendes opplevelse av tillit $(16,17)$. I denne studien viste analysene at spørsmålene korrelerte lavt med andre spørsmål som omhandler tillit, og dermed reflekterer de ikke samme egenskap (21). Forskjeller i resultatene kan tilskrives sammensetningen av utvalgene, med det kan heller ikke utelukkes at danske og norske pårørende hadde ulike opplevelser om betydningen av det fysiske miljøet når det gjaldt opplevelsen av tillit og samarbeid.

Faktor sju og faktor åtte utgår fra dimensjonen «kvalitet på kontakt med pleiepersonalet», og fortolkning tyder på at de nye faktorene måler henholdsvis «pleiepersonalets aksept og forståelse for pårørendes situasjon» og «pleiepersonalets tilgjengelighet og tilfredshet med kontakt». Teoretisk knyttes de til samarbeid da tilgjengelighet og imøtekommenhet er forutsetninger for kontakt og kommunikasjon (17). Analysene viste at flere av spørsmålene i 
disse dimensjonene hadde lave gjennomsnittsskårer. En slik «gulveffekt» framkommer når svaralternativene ikke er dekkende for det som måles, eller når instrumentet brukes i en populasjon som er forskjellig fra den det var utviklet for (21).

I strukturelle analyser har slike skjevdistribusjoner tendens til å korrelere lavere med andre spørsmål og skille seg ut (28). Fortolkningen av disse faktorene må derfor gjøres med forsiktighet, og denne analysen kan ikke bekrefte hvorvidt de gjenspeiler egne dimensjoner for begrepet samarbeid, eller hvorvidt dimensjonene er et resultat av høyt korrelerte spørsmål som måler andre egenskaper. En faktor bør dessuten bestå av minst tre spørsmål (21), og faktor sju oppfyller ikke dette kriteriet.

\section{NORSKE PÅRøRENDE SKÅRET LAVERE}

Norske pårørende skåret i gjennomsnitt lavere enn de danske pårørende i alle dimensjonene (17), noe som indikerer at de samarbeidet mer med pleiepersonalet. Forskjellene kan også tilskrives ulikheter i måten samhandling og samarbeid med pårørende blir organisert på, men dette vet vi ikke sikkert.

\section{«Norske pårørende skåret i gjennomsnitt lavere enn de danske pårørende i alle dimensjonene, noe som indikerer at de samarbeidet mer med pleiepersonalet.»}

Forskjeller i resultater mellom et originalt og et oversatt instrument kan tilskrives oversettelsesprosedyren, der ordlegging og begrepsbruk kan føre til at spørsmålene forandrer mening, eller framkomme på grunn av kulturelle ulikheter (21). Disse momentene tok vi høyde for i oversettelsesprosedyren, og målsettingen var at instrumentet skulle være ekvivalent med den originale versjonen. Likhet $\mathrm{i}$ ordlegging og mening betyr semantisk ekvivalens $(18,20)$, og sammenlikning av den originale og den tilbakeoversatte versjonen av skjemaet viste en tilfredsstillende grad av slik ekvivalens. Den opprinnelige faktorløsningen som utgjør instrumentets fem dimensjoner, gjenspeilte seg delvis i resultatene videre.

Utvalgsstørrelsen på 147 deltakere kan påvirke resultatene for instrumentets begrepsvaliditet. Ifølge Field (23) framkommer en stabil faktorløsning i utvalg med mer enn 300 deltakere, og fortolkning av faktorer med lav faktorladning skal gjøres med forsiktighet $\mathrm{i}$ små utvalg (23). Andre anbefalinger påpeker at det bør være minst tre deltakere per variabel, der ti respondenter per variabel ansees som et godt grunnlag for analyser (18).

I studien vår var ratioen 3,3 deltakere per variabel, noe som er innenfor nederste anbefalte grense. I tillegg viste KMO-test at utvalget var over middels tilstrekkelig, og analysen var dermed berettiget (23). Utvalgsstørrelsen bør likevel tas med i betraktning når faktorstrukturen og stabiliteten i denne vurderes. Lindhardt og medarbeidere foretok faktoranalysen av den originale versjonen i et utvalg på 158 deltakere (17), og vi kan dermed ikke utelukke at forskjellene i faktorløsningene kan tilskrives utvalgsstørrelsen i begge studiene. 


\section{KONKLUSJON}

Vi oversatte instrumentet The Family Collaboration Scale (FCS) fra dansk til norsk i henhold til internasjonale kriterier. Den norske versjonen har tilfredsstillende reliabilitet, og eksperter og pretest-deltakerne bedømte dets innholdsvaliditet som god. Våre analyser av begrepsvaliditeten viste at faktorstrukturen delvis er sammenfallende med de fem opprinnelige dimensjonene.

Enkeltspørsmål skilte seg ut ved ikke å inngå i sin opprinnelige dimensjon, ved å danne nye faktorer eller ved å utgå fra analysen. Instrumentet bør derfor testes i et større, heterogent utvalg, og det bør utføres bekreftende faktoranalyse for å teste de hypotetiske sammenhengene mellom spørreskjemaets opprinnelige dimensjoner før videre bruk.

I henhold til anbefaling fra forfatteren av spørreskjemaet bør det utarbeides en kortversjon til bruk for de eldste pårørende (17). For å utvide instrumentets bruksområder bør det vurderes å tilpasse og teste FCS i andre pårørendegrupper enn de som er inkludert i denne studien, for eksempel pårørende til pasienter som har vært innlagt for kirurgisk behandling eller intensivbehandling.

\section{REFERANSER}

1. Meld. St. 47 (2008-2009). Samhandlingsreformen: Rett behandling - på rett sted - til rett tid. Oslo: Helse- og omsorgsdepartementet; 2009.

2. Lov 2. juli 1999 nr. 63 om pasient- og brukerrettigheter (pasient og brukerrettighetsloven). Tilgjengelig fra: https://lovdata.no/dokument/NL/lov/1999-07-02-63 (nedlastet 25.08.2017).

3. Meld. St. 10 (2012-2013). God kvalitet - trygge tjenester: Kvalitet og pasientsikkerhet i helse- og omsorgstjenesten. Oslo: Helse- og omsorgsdepartementet; 2012.

4. Bentley J. Older people as health service consumers 4: disempowered or disinterested? British Journal of Community Nursing. 2003;8(4):181-7.

5. Foss C, Hofoss D, Romøren TI, Bragstad LK, Kirkevold M. Eldres erfaringer med utskrivning fra sykehus. Sykepleien Forskning. 2012(4):324-33. Tilgjengelig fra: https://sykepleien.no/forskning/2012/11/eldres-erfaringer-med-utskrivning-fra-sykehus (nedlastet 25.08.2017).

6. Helles $\varnothing$ R, Eines J, Fagermoen MS. The significance of informal caregivers in information management from the perspective of heart failure patients. Journal of clinical nursing. 2012;21(3-4):495-503.

7. Foss C, Hofoss D. Elderly persons' experiences of participation in hospital discharge process. Patient Education and Counseling. 2011;85(1):68-73.

8. Allen D. Negotiating the role of expert carers on an adult hospital ward. Sociology of Health \& Illness. 2000;22(2):149-71.

9. Li H, Stewart BJ, Imle MA, Archbold PG, Felver L. Families and hospitalized elders: A typology of family care actions. Research in Nursing \& Health. 2000;23(1):3-16.

10. Norsk Sykepleierforbund. Yrkesetiske retningslinjer for sykepleiere. Tilgjengelig fra: https://www.nsf.no/vis-artikkel/2193841/17102/Yrkesetiske-retningslinjer (nedlastet 
04.11.2016)

11. Lindhardt T, Bolmsjö IA, Hallberg IR. Standing guard - being a relative to a hospitalised, elderly person. Journal of Aging Studies. 2006;20(2):133-49.

12. Lindhardt T, Hallberg IR, Poulsen I. Nurses' experience of collaboration with relatives of frail elderly patients in acute hospital wards: A qualitative study. International Journal of Nursing Studies. 2008;45(5):668-81.

13. Hertzberg A, Ekman SL, Axelsson K. ?Relatives are a resource, but...?: Registered Nurses' views and experiences of relatives of residents in nursing homes. Journal of Clinical Nursing. 2003;12(3):431-41.

14. Ward-Griffin C, McKeever P. Relationships between nurses and family caregivers: Partners in care? Advances in Nursing Science. 2000;22(3):89-103.

15. Voutilainen $\mathrm{P}, \mathrm{Backman} \mathrm{K}$, Isola A, Laukkala $\mathrm{H}$. Family members' perceptions of the quality of long-term care. Clinical Nursing Research. 2006;15(2):135-49.

16. Lindhardt T, Nyberg P, Hallberg IR. Collaboration between relatives of elderly patients and nurses and its relation to satisfaction with the hospital care trajectory. Scandinavian Journal of Caring Sciences. 2008;22(4):507-19.

17. Lindhardt T, Nyberg P, Hallberg IR. Relatives' view on collaboration with nurses in acute wards: Development and testing of a new measure. International Journal of Nursing Studies. 2008;45(9):1329-43.

18. Polit DF, Beck CT. Nursing research: Generating and assessing evidence for nursing practice (9. utg.). Philadelphia: Wolters Kluwer Health; 2012.

19. Beyer N, Magnusson P, Thorborg K. Målemetoder i forebyggelse, behandling og rehabilitering: Teori og anvendelse. 2. utg. København: Munksgaard; 2012.

20. Beaton DE, Bombardier C, Guillemin F, Ferraz MB. Guidelines for the process of cross-cultural adaptation of self-report measures. Spine. 2000;25(24):3186-91.

21. de Vet HCW, Terwee CB, Mokkink LB, Knol DL. Measurement in medicine : A practical guide. Cambridge: Cambridge University Press; 2011.

22. Wahl AK, Hanestad BR. Måling av livskvalitet i klinisk praksis: En innføring. Bergen: Fagbokforlaget; 2004.

23. Field A. Discovering statistics using IBM SPSS statistics (4. utg.). Los Angeles: SAGE; 2013.

24. Crow R, Gage H, Hampson S, Hart J, Kimber A, Storey L et al. The measurement of satisfaction with healthcare: Implications for practice from a systematic review of the literature. Health Technology Assessment. 2002;6(32):1-244.

25. Eikemo TA, Clausen TH. Kvantitativ analyse med SPSS : En praktisk innføring i kvantitative analyseteknikker (2. utg.). Trondheim: Tapir akademisk forlag; 2012.

26. Walters SJ. Quality of life outcomes in clinical trials and health-care evaluation: A 
practical guide to analysis and interpretation. Hoboken: Wiley; 2009.

27. Schreiber JB, Nora A, Stage FK, Barlow EA, King J. Reporting structural equation modeling and confirmatory factor analysis results: A review. The Journal of Educational Research. 2006;99(6):323-38.

28. Clark LA, Watson D, Butcher JN. Constructing validity: Basic issues in objective scale development. Psychological Assessment. 1995;7(3):309-19. 